\title{
Pengembangan Model Tarian Bonet untuk Kebugaran Jasmani dalam Pembelajaran Penjasorkes di Sekolah Dasar
}

\author{
Ramona Mathias Mae \\ Universitas Kristen Artha Wacana Kupang. Jalan Adisucipto 147, Oesapa, Kupang, Indonesia \\ Email: maeramona@gmail.com
}

Received: 27 January 2017; Revised:8 March 2017; Accepted: 26 April 2017

\begin{abstract}
Abstrak
Penelitian ini bertujuan untuk menghasilkan model tarian bonet untuk kebugaran jasmani dalam pembelajaran Penjasorkes di sekolah dasar (SD) yang layak digunakan guru sekolah dasar sebagai salah satu bentuk model pembelajaran Penjasorkes yang bervariasi dan menyenangkan. Penelitian pengembangan ini dilakukan dengan langkah-langkah penelitian sebagai berikut: (1) pengumpulan informasi di lapangan, (2) melakukan analisis terhadap informasi yang telah dikumpulkan, (3) mengembangkan produk awal (draf model), (4) validasi ahli dan revisi, (5) uji coba lapangan skala kecil dan revisi, (6) uji coba lapangan skala besar dan revisi, dan (7) pembuatan produk final. Uji coba skala kecil dilakukan terhadap 20 siswa SD Inpres Oebesa Soe. Uji coba skala besar dilakukan terhadap 25 siswa SD Inpres Oefatu Soe. Instrumen pengumpulan data yang digunakan yaitu: (1) angket, (2) lembar pedoman observasi tarian bonet, dan (3) lembar format penilaian anak. Teknik analisis data yang dilakukan yaitu analisis deskriptif kuantitatif dan analisis deskriptif kualitatif. Penelitian ini menghasilkan senam tarian bonet untuk kebugaran jasmani dalam pembelajaran Penjasorkes di SD. Produk penelitian pengembangan berupa buku pedoman senam tarian bonet dan DVD pembelajaran senam tarian bonet untuk kebugaran jasmani dalam pembelajaran Penjasorkes di SD. Dari hasil penilaian para ahli, dapat ditarik kesimpulan bahwa model tarian bonet untuk kebugaran jasmani yang dibuat layak digunakan untuk pembelajaran Penjasorkes di SD.
\end{abstract}

Kata Kunci: pengembangan, tarian bonet, kebugaran jasmani, sekolah dasar

\section{Developing Bonet Dance for Physical Fitness in Physical Education in the Elementary School}

\begin{abstract}
This study aims to produce a model of bonet dance for physical fitness in physical education in elementary school appropriate as a form of learning models which are varied and fun. This developmental research was carried out following the steps as follows: (1) collecting information in the field, (2) conducting an analysis of the information that had been collected, (3) developing the initial products (draft model), (4) expert validation and revision, (5) small-scale field trials and revisions, (6) large-scale field trials and revisions, and (7) manufacture of the final product. The Small-scale trials were carried out to 20 studens of Oebesa Soe elementary school. Large-scale trials were conducted to 25 studens of Oefatu Soe elementary school. The data collection instruments used were; (1) questionnaire, (2) sheets of bonnet dance observation, and (3) a child assessment sheet format. The Techniques of data analysis used were descriptive quantitative analysis and qualitative descriptive analysis. This study resulted in a gymnastics bonet dance for physical fitness in physical education in elementary school. The developed product is a form of gymnastic dance manuals and instructional DVD of bonet dance for physical fitness in physical education in elementary school. From the results of the expert evaluations of the materials, it can be concluded that the developed model for physical fitness bonet dance is fit for use for teaching physical education in elementary school.
\end{abstract}

Keywords: development, bonet dance, physical fitness, elementary school

How to Cite: Mae, R. (2017). Pengembangan model tarian bonet untuk kebugaran jasmani dalam pembelajaran penjasorkes di sekolah dasar. Jurnal Keolahragaan, 5(1), 81-89. doi:http://dx.doi.org/10.21831/jk.v5i1.12772

Permalink/DOI: http://dx.doi.org/10.21831/jk.v5i1.12772 


\section{PENDAHULUAN}

Wilayah Republik Indonesia yang terdiri atas ribuan pulau, besar dan kecil, mempunyai penduduk yang terdiri atas berbagai suku bangsa, bahasa lokal, adat-istiadat dan kebiasaan, serta kebudayaan yang berbeda-beda pula. Semuanya itu merupakan potensi pembangunan, yang patut dipelihara serta dikembangkan, untuk menunjang pembangunan bangsa dan negara Indonesia. Daerah Kabupaten Timor Tengah Selatan (TTS) adalah salah satu kabupaten yang terletak di Provinsi Nusa Tenggara Timur. Penduduk asli TTS merupakan suku bangsa dawan, rumah tradisionalnya disebut Lopo. Lopo adalah lambang rumah untuk laki-laki sedangkan untuk wanita disebut ume. Kabupaten TTS memiliki suatu jenis pertunjukan rakyat berupa tarian yang dikenal dengan sebutan bonet, yang berasal dari kata "Na Bonet" yang mempunyai arti mengepung, mengurung, mengelilingi/ melingkar.

Bonet bukanlah istilah asing bagi masyarakat TTS. Bonet sudah menjadi tradisi lisan turun-temurun sejak dahulu kala. Lewat bonet masyarakat dapat mengekspresikan dan mengungkapkan perasaan melalui syair dan pantun pada upacara-upacara adat. Bonet adalah warisan budaya yang menjadi salah satu bagian dari sastra lisan yang mewarnai budaya Kabupaten TTS. Untuk melakukan tarian bonet, sekumpulan orang membentuk lingkaran, yang satu dengan lainnya saling bergandengan tangan dan berputar sambil melantunkan pantun dan syairsyair. Bentuk lingkaran dengan bergandengan tangan dipercaya masyarakat TTS melambangkan persatuan dan kesatuan tiga suku yaitu, suku Amanatun, suku Amanuban, dan suku Mollo (Fobia, 1991).

Tarian merupakan bagian penting bagi manusia, terutama bagi anak-anak, mengajarkan tarian bagi anak-anak secara spesifik akan membawa banyak manfaat antara lain untuk meningkatkan kebugaran fisik, koordinasi tubuh, percaya diri dan konsentrasi, melatih komitmen dan disiplin, sosialisasi dan kerja sama tim, penyaluran emosi bagi anak. Menari adalah kegiatan yang disukai banyak orang karena menjadi salah satu aktivitas fisik yang dapat memberikan manfaat bagi kesehatan tubuh. Dari beberapa pendapat tersebut tarian bonet dan olahraga memiliki manfaat yang sama bagi tubuh jika dilihat dari aktivitas fisik yang dilakukan oleh siswa.

Tarian bonet secara eksplesit termuat dalam ruang lingkup materi pendidikan jasmani olahraga dan kesehatan (Penjasorkes) aspek permainan dan olahraga. Materi permainan dan olahraga yang secara eksplisit disebutkan sebagai berikut: Permainan dan olahraga meliputi: olahraga tradisional, permainan, eksplorasi gerak, keterampilan lokomotor, nonlokomotor, dan manipulatif, atletik, kasti, rounders, kippers, sofball, baseball, bola tangan, sepak bola, bola voli, bola basket, tenis meja, tennis, bulu tangkis, dan beladiri serta aktivitas lainnya (Badan Standar Nasional Pendidikan, 2006, p. 244).

Dengan demikian yang dimaksud dengan olahraga tradisional dalam penelitian ini adalah serangkaian aktivitas fisik dengan menggunakan tarian bonet yang dilakukan secara teratur, terukur, dan terprogram dapat memberikan dampak positif bagi pelakunya, misalnya tubuh menjadi sehat dan bugar.

Dalam rangka mewujudkan tujuan pendidikan nasional dalam Undang-Undang Sistem Pendidikan Nasional, Nomor 20, Tahun 2003 disebutkan bahwa fungsi dan tujuan pendidikan nasional adalah sebagai berikut.

Pendidikan Nasional berfungsi mengembangkan kemampuan dan membentuk watak serta peradapan bangsa yang bermartabat dalam rangka mencerdaskan kehidupan bangsa bertujuan untuk berkembangnya potensi siswa agar menjadi manusia yang beriman dan bertakwa kepada Tuhan yang Maha Esa, berakhlak mulia, sehat, berilmu, cakap, kreatif, mandiri, dan menjadi warga negara yang demokrasi dan bertanggung jawab (Presiden Republik Indonesia, 2003).

Pemerintah telah melakukan berbagai upaya seperti memasukkan mata pelajaran Penjasorkes di dalam kurikulum sekolah. Pendidikan merupakan salah satu faktor yang menentukan terwujudnya masyarakat adil dan makmur, serta meningkatkan kualitas manusia, sebab pendidikan diselenggarakan secara demokratis dan berkeadilan serta tidak diskriminatif dengan menjunjung tinggi hak asasi manusia, nilai keagamaan, nilai kultur, dan kemajemukan bangsa. Penjasorkes merupakan pendidikan yang menggunakan aktivitas fisik sebagai media untuk mencapai tujuan yang diharapkan. Salah satu komponen penunjang pelaksanaan pendidikan jasmani agar dapat berjalan dengan baik adalah kurikulum. Dengan adanya kurikulum, peningkatan mutu dan relevansi pendidikan dapat dilakukan secara menyeluruh. Adapun cakupan pengembangan secara menyeluruh meliputi 
pengembangan dimensi manusia Indonesia seluruhnya. Untuk mewujudkan tujuan pendidikan, pelaksanaan pendidikan amat dituntut tanggung jawabnya. Dalam perkembangan kehidupan dewasa ini, tugas guru tampaknya semakin hari semakin berat.

Guru selalu dituntut untuk mampu melaksanakan proses pembelajaran sesuai dengan bidang keahliannya sehingga dapat meningkatkan martabat guru. Salah satu masalah pokok dunia pendidikan adalah pengajaran. Kegiatan pengajaran akan melibatkan berbagai komponen antara lain guru, siswa, dan faktor pendukung lainnya. Apabila salah satu komponen tidak berfungsi dengan baik, kegiatan pengajaran akan terganggu sehingga pencapaian tujuan pendidikan tidak akan tercapai.

Pembelajaran Penjasorkes di sekolah khususnya di SD saat ini sudah menjadi perhatian banyak kalangan, namun yang menjadi kendala dalam pembelajaran Penjasorkes di sekolahsekolah adalah masih minimnya pengetahuan guru Penjasorkes dalam menerapkan model dan metode yang tepat dalam proses pembelajaran di SD. Hal ini disebabkan oleh kurangnya pengetahuan dan keterbatasan referensi atau sumber bacaan tentang bagaimana guru-guru Penjasorkes mengajarkan model dan metode pembelajaran yang tepat, guna mendukung tercapainya hasil belajar yang diinginkan.

Hamalik (2009, p. 1) mengemukakan kedudukan dan fungsi guru cenderung lebih dominan sehingga keterikatan guru dalam strategi itu tampak lebih besar, sedangkan keefektifan siswa masih terlalu kecil kadarnya. Gejala ini sekaligus menggambarkan bahwa penggunaan strategi masih terbatas pada satu atau dua metode saja, belum meluas dan mencakup penggunaan metode secara luas dan banyak variasinya. Implikasi keadaan ini mengakibatkan hasil belajar siswa belum mencapai taraf optimal.

Peranan guru Penjasorkes yang baik akan terwujud apabila guru memiliki inisiatif, kreativitas, inovasi, dan dapat membuat model pembelajaran yang menyenangkan siswanya, sesuai dengan pembelajaran yang menyenangkan. Guru harus mampu menyajikan program pembelajaran dengan model dan metode yang menarik dan sesuai bagi siswa. Siswa akan merasa senang dalam proses belajarnya jika seorang guru menggunakan alat-alat atau media tersebut dalam wujud yang sederhana.

Ali $(2014$, p. 1) menyatakan inti proses pendidikan secara formal adalah mengajar, sedangkan inti proses pengajaran adalah siswa belajar. Oleh karena itu mengajar tidak dapat dipisahkan dari belajar, sehingga dalam peristilahan mengenal ungkapan proses belajar mengajar yang disebut PBM.

Menyadari arti pentingnya aktivitas gerak bagi anak SD, peneliti melakukan observasi pelaksanaan pembelajaran Penjasorkes di SD Inpres Oefatu Soe. Peneliti melakukan kajian terhadap muatan kurikulum. Hal ini dilakukan untuk mengetahui bagaimana muatan-muatan kurikulum yang terdapat di dalam standar kompetensi, apakah kompetensi dasar sudah sesuai atau belum dengan keadaan sebenarnya pada proses pembelajaran Penjasorkes di lapangan.

Berdasarkan kajian awal terhadap muatan kurikulum dalam standar kompotensi yang dilaksanakan di lapangan, gerakan-gerakan pada tarian pada bonet monoton (berputar satu arah) dan kurang bervariasi (gerakan kaki bergerak ke satu arah) sehingga tidak dapat meningkatkan kebugaran dan kesehatan bagi siswa. Dari hasil observasi pelaksanaan pembelajaran tarian bonet di lapangan, guru Penjasorkes SD Inpres Oefatu Soe belum mampu melakukan variasi-variasi gerakan hal ini disebabkan oleh kurangnya pengalaman dalam mengajar di lapangan dan bersifat klasik sehingga minimnya pembaruan dalam pembelajaran di lapangan.

Penyelidikan awal tersebut membuat peneliti tertarik untuk mengungkapkan lebih lanjut dengan masalah yang ada, sehingga peneliti dapat mencari solusinya dengan menganalisis kebutuhan di lapangan. Oleh karena itu dilakukan pengkajian lebih mendalam terhadap pelaksanaan pembelajaran, khususnya pembelajaran Penjasorkes untuk lebih mengetahui kondisi nyata di lapangan. Pengkajian dilakukan terhadap pembelajaran tarian bonet karena pembelajaran tersebut berkaitan dengan aktivitas gerak dasar siswa. Selain itu, peneliti juga ingin mengetahui permasalahan yang dihadapi guru dalam pembelajaran Penjasorkes khususnya tarian bonet di lapangan.

Masalah pertama yang dihadapi guru SD Inpres Oefatu Soe dalam pelaksanaan pembelajaran tarian bonet yaitu minimnya pengetahuan guru Penjasorkesorkes dalam menerapkan model dan metode yang tepat dalam proses belajar mengajar di SD sehingga berpengaruh terhadap cara guru mengajar di lapangan. Pembelajaran tarian bonet yang sama setiap tahunnya tanpa ada modifikasi atau pembaharuan gerak sehingga bersifat monoton. Masalah kedua dalam pelaksanaan pembelajaran Penjas- 
orkes lapangan minimnya sarana dan prasarana olahraga yang dimiliki, kurang mendapat subsidi dari pemerintah mengakibatkan indikatorindikator dari kurikulum tidak dapat terlaksana dengan baik. Dari proses analisis terhadap hasil observasi, peneliti berencana mngembangkan suatu bentuk model pembelajaran yang dapat meningkatkan kebugaran jasmani sekaligus dapat meningkatkan keterampilan motorik siswa.

Terkait dengan hal ini, sangat dibutuhkan studi yang matang dan mendalam, mengenai model dan metode yang tepat untuk pembelajaran Penjasorkes. Dengan demikian melalui penelitian ini diharapkan akan didapat solusi atau jawaban tentang model dan metode pembelajaran yang tepat untuk mengajarkan pembelajaran pada siswa SD.

Peneliti mencoba menerapkan model dan metode ini di SD Inpres Oebesa Soe di TTS. Metode yang dikembangkan dalam penelitian ini adalah dengan model pembelajaran senam bonet pada siswa SD, diharapkan siswa dapat menguasai gerakan-gerakan tarian bonet yang akhirnya memberikan kontribusi pada kebugaran jasmani siswa.

\section{METODE}

Penelitian dan pengembangan ini diakukan mulai buan Maret sampai bulan April. Studi pendahuluan dilakukan di SD Inpres Oebesa Soe. Tempat uji coba lapangan skala kecil dilakukan di SD Inpres Oebesa Soe, sementara uji coba skala besar dilakukan di SD Inpres Oefatu Soe. Subjek coba dalam penelitian pengembangan ini adalah siswa SD. Uji coba lapangan skala kecil dilakukan terhadap siswa sekolah dasar Inpres Oebesa Soe TTS yang berjumlah 20 anak. Uji coba lapangan skala besar dilakukan terhadap siswa SD Inpres Oefatu Soe TTS yang berjumlah 25 anak.

\section{Prosedur Penelitian dan Pengembangan}

Prosedur pengembangan dalam penelitian ini sejalan dengan langkah-langkah penelitian pengembangan menurut Gall, Gall, \& Borg (2007, p. 570) yang terdiri atas sepuluh langkah, yaitu: (1) studi pendahuluan, (2) perencanaan, (3) desain draf awal, (4) validasi draf awal, (5) revisi desain, (6) uji coba produk, (7) revisi produk, (8) uji coba produk, (9) revisi produk final, (10) produk massal.

Langkah-langkah tersebut diadaptasi menjadi tujuh prosedur penelitian pengembangan berikut ini:
Pengumpulan Informasi di Lapangan

Peneliti melakukan kajian awal mengenai muatan kurikulum pendidikan jasmani di SD, dan berasumsi bahwa terdapat permasalahan yang dihadapi guru Penjasorkes SD dalam pelaksanaan pembelajaran tarian bonet. Peneliti melakukan wawancara langsung dengan guru Penjasorkes SD Inpres Oebesa dan guru Penjasorkes SD Inpres Oefatu Soe TTS.

Berdasarkan hasil wawancara dan observasi (studi pendahuluan) terungkap permasalahan-permasalahan yang dihadapi oleh guru Penjasorkes terkait dengan pembelajaran tarian bonet sebagai berikut: (1) kurangnya pengalaman dan kreativitas yang diajarkan oleh guru Penjasorkes dalam menyusun model pembelajaran tarian bonet, sehingga berpengaruh terhadap proses pembelajaran yang masih bersifat klasik, (2) kondisi sarana dan prasarana yang kurang memadai di SD, dan (3) kurangnya perhatian pemerintah dalam meningkatkan kompetensi guru.

Analisis terhadap Informasi yang telah Dikumpulkan

Analisis dilakukan terhadap data hasil studi pustaka dan wawancara. Analisis terhadap hasil studi pustaka digunakan untuk pemantapan dalam memfokuskan masalah yang dikaji. Sementara analisis terhadap hasil wawancara dilakukan untuk mengetahui kebenaran asumsi peneliti dari kondisi nyata di lapangan mengenai permasalahan-permasalahan yang dihadapi guru Penjasorkes SD dalam pembelajaran tarian bonet di lapangan.

\section{Mengembangkan Produk Awal}

Setelah proses analisis, peneliti mulai mengembangkan suatu produk awal (draf awal) model tarian bonet. Produk ini masih berupa produk awal dan dalam pengembangannya dilakukan hal-hal sebagai berikut: (1) menganalisis muatan materi pembelajaran tarian bonet dan Standar Kompetensi (SK)/Kompetensi Dasar (KD) yang ingin dicapai dalam kurikulum Penjasorkes SD, agar produk yang dikembangkan tidak menyimpang dari panduan kurikulum yang ada, (2) menganalisis karakteristik siswa $\mathrm{SD}$, (3) menganalisis tujuan pengembangan model tarian bonet.

\section{Validasi Ahli dan Revisi}

Sebelum dilakukan uji coba skala kecil terhadap produk awal, produk harus mendapat validasi dari ahli materi, yaitu: (1) pakar pem- 
belajaran Penjasorkes, (2) pakar pembelajaran senam, dan (3) pakar Penjasorkes (guru Penjasorkes SD). Tujuan validasi ahli adalah untuk mendapatkan pengesahan serta masukan terhadap draf produk awal yang dikembangkan, sehingga produk layak untuk diujicobakan di lapangan.

Pada proses validasi, para ahli materi menilai dan memberikan masukan terhadap produk awal. Berdasarkan hal tersebut, dilakukan revisi terhadap produk awal. Proses revisi ini terus dilakukan sampai produk awal mencapai batas nilai tertentu yang telah ditetapkan, valid dan layak diujicobakan.

\section{Uji Coba Lapangan Skala Kecil dan Revisi}

Uji coba lapangan skala kecil dilakukan dan didokumentasikan dalam bentuk Video Compact Disc (DVD), yang kemudian diobservasi oleh para ahli materi. Penilaian oleh para ahli dilakukan terhadap substansi model dan keefektifan model tarian bonet yang dikembangkan, dengan menggunakan pedoman observasi yang disusun oleh peneliti. Masukan yang diterima dari para pakar dan guru Penjasorkes SD ditindaklanjuti dengan melakukan revisi produk. Selain itu, masukan dari guru Penjasorkes pelaku uji coba juga dipertimbangkan sebagai bahan untuk merevisi produk.

\section{Uji Coba Lapangan Skala Besar dan Revisi}

Proses yang dilakukan pada tahap uji coba lapangan skala besar serupa dengan proses yang dilakukan pada tahap uji coba skala kecil. Hal yang membedakan terletak pada jumlah subjek uji coba skala besar yang lebih banyak daripada uji coba skala kecil. Dalam hal ini subjek uji coba yang sudah mengikuti uji coba skala kecil tidak turut serta dalam uji coba skala besar. Proses revisi produk dilakukan setelah mendapat masukan dari para ahli materi untuk menghasilkan produk final. Masukan dari guru Penjasorkes SD pelaku uji coba skala besar juga dipertimbangkan sebagai bahan untuk merevisi produk.

\section{Pembuatan Produk Final}

Setelah melalui berbagai proses uji coba lapangan dan revisi, dilakukan penyusunan dan pembuatan produk akhir (produk final) berupa DVD pembelajaran model tarian bonet untuk kebugaran jasmani anak SD dan buku panduan pembelajaran model tarian bonet untuk kebugaran jasmani anak SD yang berisikan 16 gerakan masing-masing terdiri atas: (1) empat gerakan pemanasan, (2) delapan gerakan inti, dan (3) empat gerakan pendinginan.

Data, Instrumen, dan Teknik Pengumpulan Data

Jenis data yang diperoleh dalam penelitian pengembangan ini berupa data kualitatif dan data kuantitatif. Data kualitatif berasal dari: (1) data masukan dari para ahli materi dan guru pelaku uji coba, dan (2) hasil wawancara dengan guru Penjasorkes SD. Data kuantitatif diperoleh dari: (1) data hasil penilaian skala nilai dari para ahli materi, (2) data hasil penilain observasi model dari para ahli materi, (3) data kuesioner siswa. Data-data tersebut digunakan untuk mengevaluasi pengembangan model tarian bonet untuk kebugaran jasmani dalam pembelajaran Penjasorkes di SD.

Instrumen yang digunakan untuk mengumpulkan data dalam penilaian dan pengembangan ini terdiri atas: (1) pedoman wawancara, (2) angket skala nilai, dan (3) pedoman observasi model, (4) pedoman observasi keefektifan model, dan (5) kuesioner untuk siswa.

Pedoman umum wawancara berisi daftar pertanyaan yang merupakan garis besar tentang hal mendasar yang akan ditanyakan. Pewawancara berhak mengembangkan pertanyaan untuk memperdalam informasi. Pelaksanaan wawancara dilakukan secara terbuka sehingga informan mengetahui bahwa sedang diadakan penelitian dan informan menjadi salah satu sumber informasi. Moleong, (2010, p.187) menyatakan bahwa jenis wawancara terbuka mengharuskan pewawancara membuat kerangka dan garis besar pokok-pokok yang dirumuskan, namun tidak perlu ditanyakan secara berurutan.

Wawancara yang dilakukan yaitu wawancara bebas terpimpin, yaitu pedoman wawancara yang digunakan sebagai pegangan pewawancara dalam mewawancarai responden. Pedoman wawancara tidak berbentuk seperangkat pertanyaan, namun hanya berbentuk butir-butir pertanyaan yang perlu disampaikan, yang disusun berdasarkan masalah, submasalah, dan variabel penelitian. Butir-butir tersebut merupakan pengangan agar data yang dikumpulkan tidak menyimpang dari masalah yang ingin digali. Pewawancara membawa pedoman yang hanya merupakan garis besar tentang hal-hal yang ingin ditanyakan (Riduwan, 2007, p. 30).

Instrumen pengumpul data kedua yang digunakan yaitu skala nilai. Skala nilai digunakan untuk menilai kalayakan model tarian bonet yang dikembangkan sebelum pelaksanaan uji coba skala kecil, setelah para ahli menilai 
bahwa model tarian bonet sudah sesuai dengan unsur-unsur dalam skala nilai. Di dalam skala nilai, model tarian bonet baru dapat diujicobakan dalam uji coba skala kecil.

Kategori yang dimaksud dalam skala penilaian adalah katagori berskala lima, yaitu sangat baik, baik, cukup, kurang, dan sangat kurang. Cara penggunaan skala nilai yaitu, bilamana muncul gejala atau unsur-unsur seperti yang terdapat dalam klasifikasi data, para pakar dan guru memberikan tanda cek $(\sqrt{ })$ pada kolom kategori. Apabila gejala atau unsur-unsur seperti yang terdapat dalam klasifikasi data dinyatakan sangat baik, nilainya lima (5), apabila dinyatakan baik, nilainya empat (4), apabila dinyatakan cukup, nilainya tiga (3), apabila dinyatakan kurang, nilainya dua (2), apabila dinyatakan sangat kurang, nilainya satu (1).

\section{Teknik Analisis Data}

Teknik analisis data yang dilakukan dalam penelitian ini yaitu analisis deskriptif kuantitatif dan analisis deskriptif kualitatif. Analisis deskriptif kuantitatif dilakukan untuk menganalisis data-data berikut: (1) data skala nilai hasil penilaian para ahli materi terhadap draf model pengembangan tarian bonet sebelum pelaksanaan uji coba di lapangan, (2) data hasil observasi para ahli materi terhadap model pembelajaran tarian bonet, dan (3) data hasil observasi para ahli materi terhadap keefektifan model tarian bonet untuk kebugaran jasmani dalam pembelajaran Penjasorkes di SD.

Draf model tarian bonet untuk kebugaran jasmani dalam pembelajaran Penjasorkes di SD dianggap layak untuk diujicobakan dalam skala kecil apabila ahli materi pembelajaran Penjasorkes, olahraga dan media telah memberikan validasi dan menyatakan bahwa semua item klasifikasi dalam skala nilai dinilai "sesuai" dengan memberi tanda centang $(\sqrt{ })$ pada kolom sesuai. Dalam hal ini terdapat lima jenis nilai, yaitu hasil penilaian "sangat baik" mendapat nilai lima (5), hasil penilaian "baik" mendapat nilai empat (4), hasil penilaian "cukup" mendapat nilai tiga (3), hasil penilaian "kurang" mendapat nilai dua (2), dan hasil penilaian "sangat kurang" mendapat nilai nol (1). Jika terdapat para ahli materi berpendapat bahwa item klasifikasi kurang dan sangat kurag (nilai 2 dan 1), dilakukan pengkajian ulang terhadap model tarian bonet untuk kebugaran jasmani dalam pembelajaran Penjasorkes di SD yang dapat ditindaklanjuti dengan proses revisi. Untuk data hasil observasi para ahli materi terhadap model senam, hasil observasi "ya" mendapat nilai satu (1) dan hasil observasi "tidak" mendapat nilai nol (0). Hasil penilaian terhadap item-item observasi dijumlahkan, lalu total nilainya dikonversikan untuk mengetahui berapa kategorinya. Pengonversian nilai dilakukan dengan mengikuti standar penilaian acuan patokan (PAP). Dalam menginterpretasikan skor mentah menjadi nilai digunakan pendekatan PAP, yang akan dipaparkan berikut ini (Nurhasan, 2000, p. 282).

Tabel 1. Konversi Data Kualitatif ke Data Kuantitatif

\begin{tabular}{ccc}
\hline Skor Nilai & Kategori & Keterangan \\
\hline $182-216$ & 5 & Sangat Baik \\
$147-181$ & 4 & Baik \\
$112-146$ & 3 & Cukup \\
$77-111$ & 2 & Kurang \\
$42-76$ & 1 & Kurang Sekali \\
\hline
\end{tabular}

\section{HASIL DAN PEMBAHASAN}

\section{Data Validasi Ahli}

Dari hasil penilaian skala nilai (rating scale) yang diberikan oleh pakar/ahli materi terhadap revisi draf awal model sebelum diujicobakan di lapangan, para ahli materi, ahli pembelajaran Penjasorkes, ahli pembelajaran senam, dan ahli guru Penjasorkes SD, berpendapat bahwa model tarian bonet untuk kebugaran jasmani dalam Penjasorkes di SD yang terdiri atas 16 gerakan, yaitu: (1) empat gerakan pemanasan, (2) delapan gerakan inti, dan (3) empat gerakan pendinginan dikembangkan dengan dinilai 'baik' dengan item-item klasifikasi dalam penilaian skala nilai sehingga dinyatakan layak untuk diujicobakan di lapangan.

\section{Data Uji Coba Lapangan Skala Kecil}

Setelah mendapatkan validasi para ahli materi terhadap draf awal model tarian bonet peneliti melakukan uji coba lapangan skala kecil di SD Inpres Oebesa Soe. Dari pelaksanaan uji coba skala kecil, didapatkan data dari ahli materi bidang ahli pembelajaran Penjasorkes, bidang ahli pembelajaran senam, dan guru Penjasorkes di SD, data respons dari siswa terhadap model tarian bonet. Data-data tersebut dipaparkan beikut ini.

\section{Data Observasi Model}

Dari penilaian ahli materi terhadap observasi model tarian bonet untuk kebugaran jasmani dalam pembelajaran Penjasorkes pada uji coba skala kecil, para ahli materi menilai 
bahwa model tarian bonet yang terdiri atas 16 gerakan, yaitu: (1) empat gerakan pemanasan, (2) delapan gerakan inti, dan (3) empat gerakan pendinginan menunjukkan tidak ada subjek $(0$ $\%)$ yang memandang kurang, tidak ada subjek (0\%) yang memandang cukup, dan 3 responden (100\%) memandang baik. Total nilai para ahli semuanya terletak pada interval 46 maka pandangan para ahli materi terhadap hasil observasi model tarian bonet untuk kebugaran jasmani dalam pembelajaran Penjasorkes di SD memandang baik.

\section{Data Observasi Keefektifan Model}

Dari penilaian ahli materi terhadap observasi keefektifan model tarian bonet pada uji coba skala kecil, para ahli materi menilai bahwa model tarian bonet yang terdiri atas 16 gerakan, yaitu: (1) empat gerakan pemanasan, (2) delapan gerakan inti, (3) empat gerakan pendinginan menunjukkan tidak subjek $(0 \%)$ yang memandang kuran baik/efektif, tidak ada subjek $(0 \%)$ yang memandang cukup baik/ efektif, dan 3 responden atau ahli materi (100 $\%$ ) memandang baik/efektif. Total nilai para ahli semuanya terletak pada interval 46, maka pandangan para ahli materi terhadap hasil observasi keefektifan model tarian bonet untuk kebugaran jasmani dalam pembelajaran Penjasorkes di SD yang dikembangkan termasuk dalam kategori efektif.

\section{Uji Keefektifan Model Tarian Bonet untuk Kebugaran Jasmani dalam Pembelajaran Penjasorkes di SD}

Uji keefektifan model tarian bonet untuk kebugaran jasmani dalam pembelajaran Penjasorkes di SD dapat diketahui dari hasil unjuk kerja anak dalam melakukan pembelajaran keterampilan motorik kasar yang dinilai oleh para praktisi. Untuk data hasil uji keefektifan model tarian bonet untuk kebugaran jasmani dalam pembelajaran Penjasorkes di SD yaitu bisa melakukan "ya" mendapat nilai satu (1) dan tidak bisa melakukan "tidak" mendapat nilai nol (0). Hasil penilaian terhadap item-item uji keefektifan dijumlahkan, lalu total nilainya dikonversikan untuk mengetahui kategorinya. Pengonversian nilai dilakukan dengan mengikuti standar penilaian acuan patokan (PAP). Dalam menginterpretasikan skor mentah menjadi nilai digunakan pendekatan PAP, yang akan dipaparkan berikut ini (Nurhasan, 2000, p. 282).
Tabel 2. Pedoman Konversi Nilai

\begin{tabular}{ccc}
\hline Formula & Batasan & Kategori \\
\hline $\mathrm{X}<(\mu-1,0 \sigma)$ & $\mathrm{X}<16,67$ & Kurang \\
$(\mu-1,0 \sigma) \leq \mathrm{X}<(\mu+1,0 \sigma)$ & $16,67 \leq \mathrm{X}<33,33$ & Cukup \\
$(\mu+1,0 \sigma) \leq \mathrm{X}$ & $33,33 \leq \mathrm{X}$ & Baik \\
\hline
\end{tabular}

Tabel. 3. Hasil Penilaian Uji Keefektifan Model Tarian Bonet untuk Kebugaran

\begin{tabular}{cccccccccccc}
\hline \multirow{2}{*}{ Ahli Materi } & \multicolumn{9}{c}{ Item } & Observasi & Total \\
\cline { 2 - 5 } & $\mathbf{1}$ & $\mathbf{2}$ & $\mathbf{3}$ & $\mathbf{4}$ & $\mathbf{5}$ & $\mathbf{6}$ & $\mathbf{7}$ & $\mathbf{8}$ & Nilai \\
\hline Pakar Materi & 1 & 1 & 1 & 1 & 1 & 1 & 1 & 1 & 8 \\
Pakar Penjasorkes & 1 & 1 & 1 & 1 & 1 & 1 & 1 & 1 & 8 \\
Guru SD & 1 & 1 & 1 & 1 & 1 & 1 & 1 & 1 & 8 \\
\hline
\end{tabular}

Berdasarkan hasil tabel penilaian observasi, kefektifan model tarian bonet dimasukkan ke dalam norma kategori. Norma kategori disajikan pada Tabel 4.

Tabel 4. Penghitungan Normatif Kategorisasi

\begin{tabular}{ccc}
\hline Formula & Batasan & Kategori \\
\hline$X<(\mu-1,0 \sigma)$ & $X<2,67$ & Kurang \\
$(\mu-1,0 \sigma) \leq X<(\mu+1,0 \sigma)$ & $2,67 \leq X<5,33$ & Cukup \\
$(\mu+1,0 \sigma) \leq X$ & $5,33 \leq X$ & Baik \\
\hline
\end{tabular}

Keterangan: $\mathrm{X}=$ jumlah skor subjek; $\mu=$ rerata ideal $=1 / 2[(8 \times 1)+(8 \times 0)]=4 ; \sigma=$ simpangan baku ideal $=1 / 6[(8 \times 1)-(8 \times 0)]=1,33$.

Mengacu pada kategorisasi tersebut, hasil penilaian observasi keefektifan model tarian bonet dari para ahli materi dapat diketahui dan disajikan ke dalam Tabel 5.

Tabel 5. Distribusi Frekuensi

\begin{tabular}{cccc}
\hline Interval & Kategori & Frekuensi & Persentase \\
\hline $\mathrm{X}<2,67$ & Kurang & 0 & $0,00 \%$ \\
$2,67 \leq \mathrm{X}<5,33$ & Cukup & 0 & $0,00 \%$ \\
$5,33 \leq \mathrm{X}$ & Baik & 4 & $100,00 \%$ \\
Jumlah & & 4 & $100,00 \%$ \\
\hline
\end{tabular}

Tabel 5 menunjukkan penilaian ahli materi terhadap tarian bonet untuk kebugaran jasmani dalam pembelajaran Penjasorkes di SD tidak ada subjek $(0 \%)$ yang kategori kurang, tidak ada subjek (0\%) yang kategori cukup, dan empat responden (100\%) kategori baik.

\section{Data Kekurangan dan Masukan Ahli Materi}

Meskipun model sudah memenuhi itemitem observasi, terdapat beberapa masukan dari para ahli materi yaitu: (1) durasi waktu harus diperhatikan jangan melewati aturan FIT (frekuensi, intensitas, dan tempo), (2) gerakan model tarian bonet jangan sampai membosankan/monoton, (3) siswa harus senang pada saat melakukan tarian bonet yang sudah dikembangkan. 


\section{Data Kuesioner Siswa}

Data kuesioner untuk siswa menunjukkan bahwa respons dari siswa yang menjadi sampel pada uji coba skala kecil, secara umum memberikan respons yang positif terhadap model tarian bonet. Siswa merasa senang melakukan tarian bonet yang diajarkan di sekolah dan ingin melakukannya kembali di luar jam sekolah atau di rumah.

\section{Uji Coba Lapangan Skala Besar}

Langkah selanjutnya peneliti melakukan uji coba lapangan skala besar di SD Inpres Oefatu Soe, TTS. Dari pelaksanaan uji coba skala besar, didapatkan data dari ahli materi (bidang pembelajaran Penjasorkes bidang ahli pembelajaran senam, dan guru Penjasorkes SD meliputi: (1) data hasil observasi model tarian bonet, (2) data hasil observasi keefektifan model tarian bonet, (3) data masukan terhadap model pembelajaran model tarian bonet, dan respons dari siswa terhadap model tarain bonet. Datadata tersebut dipaparkan berikut ini.

\section{Data Observasi Model}

Observasi model tarian bonet pada uji coba skala kecil, para ahli materi menilai bahwa model tarian bonet terdiri atas 16 gerakan yaitu: (1) empat gerakan pemanasan, (2) delapan gerakan inti, dan (3) empat gerakan pendinginan. Tidak ada subjek $(0 \%)$ yang memandang kurang, tidak ada subjek $(0 \%)$ yang memandang cukup, dan 3 responden (100\%) memandang baik. Total nilai para ahli semuanya terletak pada interval 46 maka pandangan para ahli materi terhadap hasil observasi pengembangan model tarian bonet untuk kebugaran jasmani dalam pembelajaran Penjasorkes di SD memandang baik.

\section{Data Kekurangan dan Masukan Ahli Materi}

Berdasarkan hasil observasi dari ahli materi terhadap pelaksanaan uji coba skala besar model tarian bonet, para ahli materi menganggap bahwa model yang dikembangkan sudah baik dan efektif, sehingga tidak ada masukan lagi atau tidak diperlukan revisi.

\section{Data Kuesioner Siswa}

Data kuesioner untuk siswa, menunjukkan bahwa respons dari siswa yang menjadi sampel pada uji coba skala besar, secara umum memberikan respons yang positif terhadap pengembangan model tarian bonet untuk kebugaran jasmani dalam pembelajaran Penjasorkes di SD. Siswa merasa senang melakukan tarian bonet yang diajarkan dan ingin melakukan lagi di rumah dan di luar jam sekolah. Setelah mendapat penilaian dan masukan, baik dari para ahli materi maupun guru Penjasorkes SD pelaku uji coba kemudian dilakukan proses-proses revisi terhadap draf model pembelajaran model tarian bonet yang dikembangkan. Proses revisi terhadap produk model tarian bonet ini terdiri atas: (1 ) revisi draf produk awal, (2) revisi uji coba skala kecil, (3) revisi uji coba skala besar. Akhirnya dihasilkan pengembangan model tarian bonet untuk kebugaran jasmani dalam pembelajaran Penjasorkes di SD yang terdiri atas 16 gerakan yaitu: (1) empat gerakan pemanasan, (2) delapan gerakan inti, dan (3) empat gerakan pendinginan, yang disusun dalam bentuk DVD pembelajaran dan dalam bentuk buku panduan yang layak untuk digunakan.

\section{SIMPULAN DAN SARAN}

\section{Simpulan}

Berdasarkan hasil penelitian, dapat diambil kesimpulan bahwa pengembangan model tarian bonet untuk kebugaran jasmani dalam pembelajaran Penjasorkes di SD yang terdiri atas 16 gerakan yaitu: (1) empat gerakan pemanasan, (2) delapan gerakan inti, dan (3) empat gerakan pendinginan. Model tarian bonet yang dikembangkan disesuaikan dengan standar kompetensi dan kompetensi dasar yang termuat dalam kurikulum, disesuaikan dengan pertumbuhan dan perkembangan anak SD, serta disesuaikan dengan tingkat keamanan pelaksanaan kegiatan di sekolah. Uji kelayakan dilakukan berdasarkan penilaian ahli materi menunjukkan bahwa pengembangan model tarian bonet yang disusun layak untuk digunakan sebagai pembelajaran Penjasorkes di SD.

\section{Saran}

Saran pemanfaatan berdasarkan penilaian pengembangan yaitu agar model tarian bonet dapat digunakan guru sebagai salah satu bentuk pembelajaran Penjasorkes untuk meningkatkan kebugaran jasmani siswa SD. Untuk mewujudkan hal tersebut, perlu ditingkatkan kemauan dan kesediaan guru untuk senantiasa meningkatkan kualitas pembelajaran dengan berbagai bentuk model pembelajaran yang dapat meningkatkan minat dan kualitas siswa dalam belajar, meskipun hal tersebut berarti menambah kesibukan guru dalam menyiapkan bahan-bahan pembelajaran. 
Desiminasi hasil penelitian ini dapat dilakukan melalui seminar-seminar, dan dalam bentuk pembuatan artikel, atau dapat juga dilakukan melalui penelitian tindakan kelas maupun eksperimen dengan melibatkan guru SD untuk mengetahui efek nyata dari produk model tarian bonet.

Untuk mengembangkan produk lebih lanjut perlu dilakukan penelitian yang melibatkan subjek coba lebih besar dan cakupan tempat uji coba yang lebih luas. Di sisi lain, dapat juga dilakukan penelitian serupa dengan sasaran subjek siswa SD kelas bawah/anak usia dini.

\section{DAFTAR PUSTAKA}

Ali, M. (2014). Guru dalam proses belajar mengajar. Bandung: Sinar Baru Algensindo.

Badan Standar Nasional Pendidikan. (2006). Standar isi untuk satuan pendidikan dasar dan menengah: Standar kompetensi dan kompetensi dasar SMA/MA. Jakarta: Badan Standar Nasional Pendidikan.

Fobia, F. H. (1991). Bonet wadah komunikasi pembangunan di Timor Tengah Selatan.

Gall, M. D., Gall, J. P., \& Borg, W. R. (2007). Educational research: An introduction. Pearson/Allyn \& Bacon.

Hamalik, O. (2009). Proses belajar mengajar. Jakarta: Bumi Aksara.

Nurhasan. (2000). Tes dan pengukuran pendidikan olahraga. Jakarta: Kurunika.

Presiden Republik Indonesia. Undang-undang Republik Indonesia Nomor 20 Tahun 2003 tentang sistem pendidikan nasional, Pub. L. No. 20 (2003).

Riduwan. (2007). Skala pengukuran variabelvariabel penelitian. Bandung: Alfabeta. 